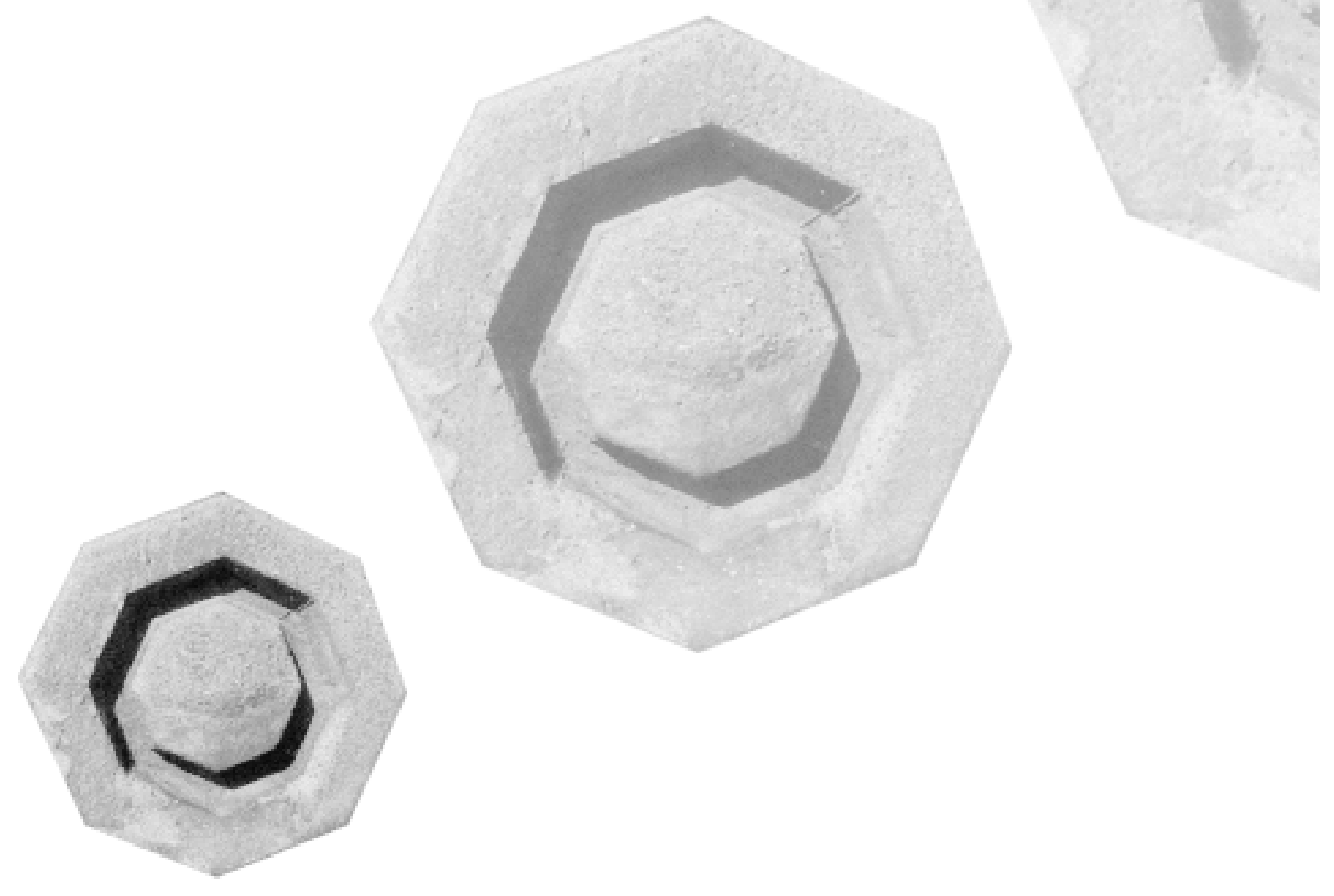


"Em todos os lares, o conforto moral da ciência e da arte": a Revista Nacional de Educação e a divulgação científica no Brasil (1932-34)

"In all bomes, the moral comfort of science and of art": the Revista Nacional de Educação and scientific dissemination in Brazil (1932-34)

\section{Regina Horta Duarte}

Professora do Departamento de História da Faculdade de Filosofia e Ciências Humanas/Universidade Federal de Minas Gerais (FAFICH/UFMG) Rua Campanha, 98/101 Cruzeiro 30310-770 Belo Horizonte - MG regina_horta@hotmail.com
DUARTE, R. H.: "Em todos os lares, o conforto moral da ciência e da arte": a Revista Nacional de Educação e a divulgação científica no Brasil (1932-34).

História, Ciências, Saúde-Manguinhos, vol. 11(1):33-56, jan.-abr. 2004.

A Revista Nacional de Educação foi editada, entre 1932 e 1934, pelo Museu Nacional do Rio de Janeiro, sob os auspícios do Ministério da Educação e Saúde Pública e direção de Roquette-Pinto. Seu objetivo principal era a veiculação de conteúdos de ciência, história e arte para um público mais amplo das várias regiões do Brasil. Os artigos são escritos por intelectuais da época, muitos deles atuantes cientistas do Museu Nacional, além de traduções de trechos de alguns viajantes. Cada um de seus números era impresso com custos reduzidos e em expressiva tiragem. Apresentando-se como iniciativa de uma República renovada, parte de uma estratégia mais ampla de inaugurar novas relações entre o governo e uma população a ser educada, a revista se autodefiniu como "um marco espiritual da nacionalidade", sintonizada ao ideal de um Estado cuja ação pedagógica constituísse um povo e uma nação.

PALAVRAS CHAVE: Revista Nacional de Educação, Museu Nacional, divulgação científica

DUARTE, R. H.: "In all homes, the moral comfort of science and of art": the Revista Nacional de Educação and scientific dissemination in Brazil (1932-34) História, Ciências, Saúde-Manguinbos, vol. 11(1):33-56, Jan.-Apr. 2004.

Between 1932 and 1934, the journal Revista Nacional de Educação was published by Rio de Janeiro's National Museum, under the auspices of the Brazilian Ministry of Education and Public Health and under the direction of Roquette-Pinto. Its main goal was to disseminate information on science, history, and art among a wide-ranging Brazilian public. The articles were written by the intellectuals of the day, many of whom were scientists at the Museu Nacional. The Revista also published translations of excerpts by a number of travelers. Every issue was published at a low cost, with a significant number of copies. The journal was touted as the initiative of a renewed Republic, part of a broader strategy of inaugurating new relations between government and a population to be educated. It defined itself as "a spiritual milestone in the Brazilian nationality" in tune with the ideal of a State whose educational initiatives were meant to constitute a people and a nation. KEYWORDS: Revista Nacional de Educação, Brazil's National Museum, scientific dissemination. 


\section{Introdução:}

Z m outubro de 1932, ares de euforia e renovação percorreram os C corredores e salas do Museu Nacional, situado no Rio de Janeiro. Estava pronto o primeiro número da Revista Nacional de Educação (RNE), publicação mensal sob a direção de Edgar Roquette-Pinto e financiada pelo Ministério da Educação e Saúde Pública. A mais recente publicação do Museu tinha uma significativa tiragem, 12.500 exemplares, número que expressava o ideal de sua ampla distribuição por todo o território do Brasil, hercúlea tarefa atribuída à Diretoria de Informações, Estatística e Divulgação do já referido Ministério. Professores, escolas, prefeituras e diversas associações culturais e de classe passaram a receber o periódico, gratuitamente. No primeiro aniversário da publicação, sua tiragem alcançou a marca dos 15 mil exemplares (Roquette-Pinto, fev. 1932, p. 5; Teixeira de Freitas, ago.-set. 1933).

Certamente, o Museu Nacional já tinha uma longa tradição de publicação científica, iniciada em 1876 com a fundação dos Arquivos do Museu Nacional, durante a direção de Ladislau Netto, com artigos de zoologia, botânica, fisiologia experimental, geologia, paleontologia, antropologia e arqueologia (Lopes, 1997, p. 240). Mas aquele era um periódico dedicado à nascente comunidade científica do Brasil e aos estudiosos dos países com os quais se fazia permuta. A RNE trazia um público-alvo muito diverso e, principalmente, ousava uma nova aposta sobre o papel do Museu Nacional na renovação da sociedade brasileira, a partir das esperanças depositadas nos novos rumos do país após 1930.

Na capa do primeiro número, o leitor agraciado com um exemplar poderia observar uma figura feminina altiva e delicada tocando um imenso foco de luz. Seria uma representação de Minerva, divindade protetora de todas as atividades intelectuais, principalmente as escolares? Nesse caso, faltar-lhe-iam a lança e o escudo característicos (Grimal, 1984, pp. 61, 359), esquecimento deveras providencial na revista de um governo que acenava, dentre outras coisas, com a pacificação social. Seria a nação brasileira? Os reflexos luminosos se espalhavam por uma paisagem algo indefinida, mas na qual se distinguem traços de habitações e montanhas, em um cenário que tanto podia ser urbano como rural. À direita, o título, a indicação do Ministério, seguidos da epígrafe que acompanhou a publicação até seu desaparecimento, em meados de 1934: "Em todos os lares do Brasil, o conforto moral da Ciência e da Arte."

O trecho destacado era de autoria de Roquette-Pinto e integrava sua apresentação da Revista, curiosamente intitulada 'Reafirmando'. Nesse breve texto, espécie de editorial, criticava "maus compatriotas", ativos difusores do pessimismo entre o povo do Brasil que apresentavam a nação como um terreno inútil, desalentando as massas e sugerindo a ruína como futuro inexorável. Roquette-Pinto certamente insistia em sua postura de crítica contra a forte corrente intelectual que apontara o 
mestiço como elemento imprestável, numa tradição que remontava a Louis Agassiz - para quem a mistura de raças no Brasil gerou um tipo biologicamente inferior - e se consolidara nas palavras de Monteiro Lobato (1984, p. 140), segundo as quais o caboclo nada mais era que um "piolho da terra", "homem baldio, seminômade, inadaptável à civilização".

$\mathrm{Na}$ acirrada polêmica em curso nos anos 1910 e 1920, muitos apontavam a população brasileira como irremediavelmente condenada, aberração conseqüente da mistura racial, como Nina Rodrigues. Outros construíam modelos de controle eugênico da população para seu aperfeiçoamento, como Renato Kehl e Miguel Couto. O $1^{\circ}$ Congresso Brasileiro de Eugenia foi palco do enfrentamento entre o grupo liderado por Kehl e o de Roquette-Pinto, que, em uma abordagem antropológica cultural, opunha-se à tese da influência do ambiente sobre a hereditariedade, negava as teorias da existência de raças inferiores e afirmava que o problema nacional não era transformar os mestiços em brancos, nem substituir os homens, mas educar todos, claros, pardos e escuros (De Luca, 1999, p. 232; Gouvêa Filho, 1955, p. 32).

O diretor da RNE, ao defender tais pontos de vista, certamente se alinhava à tradição de Cândido Rondon, para quem o sertão era o berço do mameluco, legítimo brasileiro, empreendedor, aventureiro e insubmisso. Por volta de 1912, quando Monteiro Lobato administrava as terras herdadas do avô, irritado com os homens que nela encontrara, Roquette-Pinto viajava com o sertanista pelo interior do Brasil, participando da pacificação dos nambiquaras na fronteira entre o Mato Grosso e o Amazonas, onde ajudou na fundação da estação telegráfica José Bonifácio. Na valorização do contato direto com o interior, com destaque para a denúncia do seu estado de abandono e as conseqüências funestas da inexistência de políticas públicas, autores como Euclides da Cunha e Alberto Torres eram referências importantes, propugnadores da missão do povoamento dos trópicos, do mameluco como base da nação, da idéia de um povo em estado de latência a ser despertado e assumir um grandioso papel (Lima, 1999, p. 76) .

Frente aos discursos pessimistas de alguns de seus contemporâneos, a RNE era projetada como um veículo da esperança, apresentando a história do Brasil em seu vigor, infundindo em seus leitores a convicção do valor próprio e mostrando as potencialidades a serem exploradas por um povo esclarecido. Esse seria o conforto da ciência e da arte, infundindo razão e fruição estética, a ser oferecido em cada página da revista.

\section{Forma e conteúdo}

A publicação da RNE era, segundo Roquette-Pinto, a coroação de um sonho de mais de vinte anos em sua carreira de pesquisador científico e professor. Apontava a distribuição dos milhares de exemplares 
da RNE como um marco na transformação das relações entre o governo e as classes populares, que poderiam reconhecer um dos primeiros atos de criação de valores culturais e certamente "o primeiro gesto educativo rigorosamente popular praticado pela República", já que o Museu Nacional, a Biblioteca Nacional e outras instituições do tipo haviam sido criadas por D. João VI (Roquette-Pinto, fev. 1933, p. 8).

A fundação desse periódico surgiu das Instruções para o cumprimento do decreto 21.240, de abril de 1932, que nacionalizava o serviço de censura dos filmes cinematográficos e criava a "taxa cinematográfica para a educação popular", a ser cobrada por metragem dos filmes exibidos. A longo prazo, a taxa financiaria a criação e manutenção de um Instituto Cinematográfico Educativo. Antes disso, seria destinada ao Museu Nacional para a organização de uma filmoteca e publicação "de uma revista popular de vulgarização de ciências, letras e artes", a ser distribuída em todos os institutos públicos de ensino (Diário Oficial, 1932). A Revista Nacional de Educação surgia ligada aos anseios educativos e à ação do recém-criado Ministério da Educação e Saúde Pública, então ocupado por Francisco Campos. Sua história também se confundia com a recente atenção das autoridades em relação ao cinema, seja pelo perigo em potencial que representava, seja pelo seu uso potencial como instrumento didático para a consolidação de uma nação idealizada.

Com periodicidade mensal, a Revista era impressa em papel simples, com média de 96 páginas por volume, medindo $18 \times 27 \mathrm{~cm}$. Formato e conteúdo se amalgamavam: leve, pequena, de fácil manuseio, a simplicidade material da revista era certamente intencional. Entretanto, uma vez abertas suas páginas, evidenciava-se a grande riqueza da edição. Os artigos eram numerosos, cerca de 16 por volume, na maioria curtos e invariavelmente escritos em linguagem acessivel e, sobretudo, didática. Tal característica afinava-se certamente aos ideais da Escola Nova, de cujo Manifesto Roquette-Pinto foi um dos signatários, da necessidade de abandonar-se uma cultura livresca e afastada da vida cotidiana. O livro era objeto a ser manuseado, instrumento tanto mais útil quanto mais acessível. Não deixa de ser um dado importante o fato de 1932 ser também o ano de fundação do Instituto de Educação do Rio de Janeiro, sob a direção de Anísio Teixeira, defensor da criação de uma escolalaboratório em que uma nova pedagogia se delineasse e a prática da leitura ganhasse novos significados (Vidal, 2001, pp. 101-27).

Os colaboradores da RNE eram expressivos cientistas e intelectuais da época. Uma grande parte deles pertencia ao Museu Nacional, como o zoólogo Cândido de Mello Leitão, o arqueólogo Alberto Childe, os botânicos Alberto Sampaio e Carlos Vianna Freire, o geólogo Moysés Gikovate, o antropólogo Raimundo Lopes e o próprio Roquette-Pinto, dentre outros. Publicavam-se também excertos de autores de referência, principalmente Alberto Torres, mas também Euclides da Cunha. Algumas autoridades públicas também ocuparam as páginas da revista, na 
transcrição de discursos sobre assuntos educacionais. Havia ainda alguns colaboradores esporádicos, educadores, professores, membros da Associação dos Amigos de Alberto Torres. Um outro destaque importante era o de textos, por vezes raríssimos, de eminentes naturalistas, sobre o Brasil. Nos 21 números lançados entre outubro de 1932 e junho de 1934, foram publicados 16 trechos traduzidos de Viagem ao Brasil, de Spix e Martius, além de seis fragmentos da Viagem filosófica do naturalista Alexandre Rodrigues Ferreira.

Além da notoriedade dos autores, um dos maiores trunfos da revista, na busca da receptividade pelo público leitor, era a ampla utilização de imagens, todas em preto e branco, em uma reprodução de excelente qualidade. Seu uso tinha intenções muito diversificadas. Inicialmente, tornava a revista atraente. Entretanto, não se tentava seduzir o leitor pela capa que, com exceção do primeiro número, era muito sóbria e possuía apenas uma pequena imagem à esquerda, sempre exibindo o busto desenhado de um brasileiro ilustre do qual pudéssemos nos orgulhar: Alberto Torres, Euclides da Cunha, Nísia Floresta, Pedro Américo, José Bonifácio, Carlos Gomes, Santos Dumont, Diogo Feijó e outros. Mas ao comedimento da capa contrastava o apelo das imagens que acompanham muitos artigos, além de fotos estampadas em páginas especiais. Era como um aviso ao leitor de que a simplicidade continha a densidade e o conteúdo, numa clara desvalorização das aparências enganosas e do luxo que escondiam valores questionáveis. Despojada do que Alberto Torres apontava como "lantejoulas do discurso", a revista diferenciava-se dos valores de uma cultura litorânea, na qual a vaidade e a ostentação conduziam ao rebuscamento. Só a sua abertura e o folhear cuidadoso de suas páginas revelava seus segredos. O mesmo valia para a capa, pois seu significado mais profundo só poderia ser esclarecido na seção Notas e Informações, onde era possível encontrar uma pequena biografia do homenageado, com destaque para suas obras e outras contribuições à sociedade brasileira.

As fotos internas, por sua vez, são muitas, em quantidade e beleza. Há a foto de um índio de Rondônia, de autoria do próprio RoquettePinto, em que um rapaz empunha seu arco, forte, majestoso, em harmonia com o meio natural e a paisagem que o cerca. Há fotos de brasileiros ilustres, como Vitor Meirelles e Santos Dumont, ou de nossas belezas naturais, como a vitória-régia. Há ainda imagens fotográficas de grandes pinturas de Rembrandt, Da Vinci e Miguelangelo, assim como de obras de artistas brasileiros, sendo a maior parte delas parte do acervo da Academia Nacional de Belas Artes ou do Palácio do Itamarati.

Em 'Caipiras negaceando', de Almeida Júnior, homens se misturam à natureza, por vezes quase dela indistintos, em atitude altiva, inteligente. Essa imagem encontra ressonâncias nas palavras de Euclides da Cunha (1932, p. 16), em excerto publicado em outro número da revista, para quem o sertanejo era, antes de tudo, um forte, cuja aparência ao 
primeiro lance de vista era de atonia muscular perene e preguiça invencível mas que, frente ao improviso, transformava-se, em nova estatura e novos gestos, com força e agilidade, transfigurando-se de Quasímodo em Hércules. A foto da pintura 'Bandeirantes', de Henrique Bernadelli, também do acervo da Academia de Belas Artes, foi veiculada no segundo número da RNE, representando homens em marcha, intrépidos, acompanhados pelos índios em seu desbravamento. Vários artigos publicados decantavam o seu valor, como o de Affonso Taunay, em que a breve descrição das suas estupendas façanhas associava-os a uma raça de gigantes (Taunay, abr. 1933, pp. 63-70).

Os dados biográficos e indicação de outras obras de cada um desses artistas encontravam-se na seção Notas e informações. No caso dos brasileiros, citavam-se as exposições e prêmios. O entrelaçamento e igual destaque dado às obras de pintores clássicos e artistas brasileiros pressupunha a atribuição de um grande valor a nossa produção artística. Outra intenção presente era desenvolver uma fruição estética, base cultural para um novo homem brasileiro. Afinal, a revista desejava levar o conforto moral da ciência, mas também o da arte, numa estreita associação entre a elevação moral dos sujeitos, a constituição da cultura nacional e a elaboração de sensibilidades (Veiga, 2000, p. 419).

Em reproduções que mesclavam conhecimento e prazer estético, encontram-se alguns dos desenhos inéditos das viagens de Alexandre Rodrigues Ferreira, sempre a acompanhar os longos trechos que a RNE publicou: "índio Cambeba atirando flecha com a palheta", a imagem do tatu na paisagem marcada pela ação do homem, da cobra e da capivara, do macaco prego, da maloca dos cururus. Imagens que contêm saberes valiosos para uma sociedade que assistira às excursões de Rondon e sabia do desafio da integração da Amazônia para a constituição nacional.

Outras imagens presentes são as de paisagens brasileiras, como da mata da Tijuca, do salto do Iguaçu, da cidade de Ouro Preto. Além de todas essas, avulsas e que não acompanhavam diretamente um artigo escrito, muitas outras cotejavam estrategicamente os textos, na clara intenção de aumentar sua compreensão. O conhecimento era veiculado em palavras e imagens: em textos de biologia, imagens de aranhas, formigas, folhas, caules, árvores; em textos de higiene, desenhos do corpo humano.

O interior da revista trazia, assim, uma pletora de informações. Simples e modesta por fora, abria um mundo ao seu leitor. Não um mundo distante e alheio, mas o mundo que se queria instituir como o Brasil. Se minha primeira hipótese é a de que a forma e o conteúdo da revista se completavam, uma segunda é a de que ela desejava, através de seus textos e imagens, criar uma série de referências compartilhadas (Gomes, 1999, p. 19), dirigindo-se a um público culto — professores e associações culturais -, no qual esperava encontrar agentes multiplicadores de sua ação. Publicada e distribuída pelo governo 
provisório, certamente era uma das armas na estratégia de constituição de legitimidade do novo projeto político.

\section{A nação compartilhada}

Em artigo comemorativo do primeiro aniversário da revista, Teixeira de Freitas exultava com o seu sucesso, expresso em centenas de cartas, pedidos e aplausos de todas as partes do Brasil. Instrumento de divulgação científica, órgão de educação "no melhor sentido, principalmente através da cultura do sentimento estético", levava aos lares "o pão do espírito", gerando o aprendizado coletivo "das mesmas noções, seguras e leves, em torno dos mais variados aspectos da vida, na emoção em uníssono", realizando uma cruzada patriótica, pois constituía "a mais bela, a mais eficaz, a mais extensa, a mais profunda obra até hoje tentada no Brasil de continuação da educação primária”. O governo da República cumpria um altíssimo dever ao financiar a revista, "fazendo afinal alguma coisa de sentido verdadeiramente nacional em benefício da cultura popular". Sobre todos esses aspectos, um assumia valor transcendental: ao criar um sentido de unidade, a revista contribuía - na expressão de Silvio Romero - para plasmar, embelezar e enobrecer a "grande Alma Nacional" (Teixeira de Freitas, ago.-set. 1933, pp. 53-4).

A idéia de que a RNE era um marco na atuação do governo provisório na área educacional foi recorrente em diversas falas de atores históricos, que certamente tinham perspectivas mais ou menos diferentes de como isso se daria, como Teixeira de Freitas, Roquette-Pinto e Francisco Campos, ministro da Educação que aprovou a proposta da revista. Mas, para além das diferenças, sempre era defendida como uma ação positiva do Estado, engendrando a nação através de uma prática educativa. A verba destinada pelo governo era de cerca de oito contos de réis. Contabilizando a renda dos anúncios, as despesas com material, clichês, redação e mão-de-obra, o custo de cada exemplar era calculado em quinhentos réis, numa época em que o preço de um jornal era de duzentos réis (Roquette-Pinto, fev. 1933, p. 9).

A distribuição certamente tinha o obstáculo da imensidade do território e da precariedade dos transportes, mas o próprio RoquettePinto considerava tal dificuldade como parte da luta a ser ganha, já que no Brasil caminhavam lentamente as utilidades e as idéias. Mas a revista, mesmo vagarosa na entrega, seria um fator de agilização das comunicações, pois, divulgando a ciência, daria a todos as ferramentas intelectuais necessárias para que a extensão territorial deixasse de ser um elemento antagônico, seguindo um processo já em curso: no início do século XIX, o tempo necessário para vencer a distância entre o Rio de Janeiro e Belém era de dois meses; com o navio a vapor, em meados do XIX, o tempo fora reduzido a uma quinzena e, nos anos 1930, a três dias (Roquette-Pinto, dez. 1932, p. 1). 
Justamente a extensão do território a ser vencido mostrava a grandeza da obra a ser construída. Essa ênfase da chegada da revista como o sinal da iniciativa do Estado nos rincões perdidos espalhados pelo território reforçava uma das muitas concepções então em debate pelos intelectuais da época, segundo a qual o sertão encontrava-se distante do poder público e dos projetos modernizadores. E o sertão, seguramente, podia estar bem próximo: bastava ir um pouco além da avenida Rio Branco (Lima, op. cit., p. 60; Fonseca, jan. 1933, p. 1).

As figuras da revista assumiam um papel fundamental na defesa desses argumentos, pois construíam uma imagem do que era o Brasil. Ao longo dos vários números, diferentes contracapas traziam uma gama de informações a serem significadas como parte de uma idéia geral da nação brasileira, em sua história, povo e território. Nos números quatro/dez, a primeira contracapa trazia o mapa 'O Brasil e suas fronteiras', delimitando seus limites na América Latina, mas também mostrando toda a extensão a ser ocupada e civilizada. Na contracapa final, uma tabela sobre o Brasil em 1930 com dados estatísticos diversos, numa sociedade em que a estatística era reclamada por muitos, como no caso de Fernando Azevedo, diretor geral da Instrução Pública do Distrito Federal entre 1927 e 1929, organizador de pioneiro recenseamento escolar no Rio de Janeiro, ou de Teixeira de Freitas, que afirmava a urgência de o Brasil conhecer-se "para tornar-se senhor de seu destino", pois ignorava quase tudo de si mesmo e "da soberba herança que lhe confiou a munificência divina" (Teixeira de Freitas, out. 1932, p. 56).

Os números 11 a 15 trouxeram outras imagens nas contracapas. Na primeira, o mapa das zonas populacionais criado por Roquette-Pinto, base da sua argumentação em que diferenciava raça e povo, enfatizando o aspecto cultural e histórico desse último conceito, tornando-o preferível ao primeiro. O mapa diferenciava as zonas do caboclo, a de influência africana e a de influência européia e resultava das reflexões desenvolvidas pelo autor no artigo 'O Brasil e a antropogeografia', publicado em 1927, na coletânea Seixos rolados. A segunda contracapa trazia o destaque de algumas datas da história do Brasil, iniciando com a do descobrimento, passando pelas invasões francesa e holandesa, as bandeiras, a independência, a fundação do Instituto Histórico e Geográfico, a estrada de ferro entre o Rio e Petrópolis, a abolição, a República, a ação de Oswaldo Cruz, a organização da Comissão Rondon, a instauração do governo provisório sob a presidência de Vargas e, por último, mas como uma espécie de ponto culminante que parecia dar sentido e alento à longa trajetória descrita, a fundação do Ministério de Educação.

Outras imagens publicadas nas contracapas de números seguintes eram a de um mapa geológico do Brasil, referente a um texto sobre o tema de autoria de Moysés Gikovate, do Museu Nacional; a do alfabeto grego e do alfabeto Morse. Note-se a relevância deste último se pensarmos na importância que as viagens de Rondon assumiram na instalação 
de estações telegráficas, em locais distantes de nosso território. Nos últimos seis números da revista havia um mapa-múndi com a indicação das rotas dos principais descobrimentos. A contracapa final trazia os bustos e breve biografia de grandes navegadores.

Curiosamente, tais imagens levavam ao leitor uma gama de interpretações sobre o território, a população, os aspectos naturais e físicos, os dados econômicos e, sobretudo, históricos, numa perspectiva que amalgamava população e território, sociedade e natureza, tudo isso englobado na representação da nação.

\section{Ler a nação}

Na criação e divulgação dessas referências a serem compartilhadas, minha terceira hipótese é a de que a RNE assumiu a estratégia de apresentar-se como uma espécie de cartilha escolar variada, múltipla, versátil, ligada aos fatos da realidade, pois descortinava um mundo de sinais a serem decifrados, como se o Brasil fosse um grande livro a ser lido e, para tanto, as pessoas tivessem que ser devidamente instrumentalizadas. Os artigos, muitos deles seções que acompanharam vários números da revista, continham noções elementares de várias áreas do conhecimento e da sensibilidade artística.

Em primeiro lugar, a revista desejava ser uma cartilha para a leitura da flora e da fauna brasileiras, sobre as quais o Museu Nacional possuía uma longa tradição de estudo e as contribuições dos pesquisadores eram significativas. São vários os colaboradores pertencentes àquela instituição, como Carlos Vianna Freire, presente em todos os números publicados, com a seção Noções Elementares de Botânica. Escrita em estilo simples, entremeada de inúmeros desenhos explicativos, consistia em um curso completo e detalhado sobre folhas, caule, raízes etc. Também Alberto Sampaio foi um autor constante nas páginas da revista, abordando noções básicas de botânica e história da taxonomia vegetal e métodos de classificação de plantas. Outros artigos indicam o seu envolvimento com a filmoteca do Museu Nacional, para a qual era destinada uma parte da verba advinda do mesmo decreto criador da RNE, citado anteriormente. Discorrendo sobre o babaçu e a carnaúba, a sua fitogeografia, seus usos e possibilidades econômicas, Sampaio indica que aquelas eram as anotações para filmes educativos a serem realizados pelo Museu Nacional (Sampaio, mar. 1933, pp. 37-43; abr. 1933, pp. 54-9). Essa instituição já possuía, segundo Roquette-Pinto, "um serviço de filmes educativos organizados em moldes modernos". Tais iniciativas integravam uma série de práticas nas quais o Museu era projetado como um local de educação popular, a cumprir um papel de destaque na cruzada educacional necessária para o Brasil, contando com o recurso do cinema, dentre outros (Roquette-Pinto, fev. 1933, p. 1). 
Assim como prometia a decifração da flora, a RNE acenava também com o desvendamento dos segredos da fauna do Brasil. São publicados artigos de autores diversos sobre vespas e formigas, sempre com a ênfase de serem esses insetos sociais, "seres de multidão" com reações coletivas análogas ao "espírito de multidão que caracteriza a sociedade humana" (Bouvier, jan. 1933, p, 45). A maior e mais diversificada colaboração, entretanto, é de Cândido de Mello Leitão, aracnólogo do Museu Nacional. Além de inúmeros textos sobre as aranhas, escreveu ainda sobre celentérios, vida das rãs, genética, darwinismo e monstros do mar. Sua argumentação partia sempre de elementos cotidianos, impressões vulgares, recorrendo a mitos, lendas e pequenas histórias, num efeito didático sedutor que precedia as considerações diretamente científicas sobre o tema proposto. E aqui uma nova indicação pode mais uma vez sinalizar a ação dos cientistas do Museu Nacional em um ativo projeto de popularização do saber produzido, através de meios de comunicação de massa, como os impressos, o cinema e o rádio: grande parte dos artigos de Mello Leitão integrava um programa educativo, levado ao ar às sextas-feiras, na Rádio Sociedade do Rio de Janeiro, a PRA-2, fundada por Roquette-Pinto nos anos 1920.

Divulgar o conhecimento de todas as formas possíveis, ensinar as massas a lerem o grande livro da Natureza, sem o que nunca aprenderiam a compreender o "ABC da vida", era considerado " $\mathrm{a}$ mais necessária das alfabetizações e a mais difícil delas". Este era o objetivo da seção Assuntos Agrícolas, assinada sob o pseudônimo OF, ao ensinar práticas corretas ao homem do campo, tais como modos de evitar mosquitos e vermes, técnicas de poda adequada das árvores, além de instruir sobre o modo de diferenciar os insetos daninhos daqueles úteis às plantações, através da observação de seus ovos, larvas e casulos. (OF, ago.-set. 1933, p. 83). Mas também o clima podia ser objeto de curiosidade e conhecimento. Para tanto, a seção Dicionário Meteorológico, assinada por Joaquim de Sampaio Ferraz, diretor do Instituto Meteorológico, ensinava as bases da climatologia, com verbetes de $\mathrm{A}$ a $\mathrm{Z}$ abordando práticas, instrumentos e noções essenciais. Saberes certamente úteis no âmbito de um projeto de nação em que o campo e as atividades agrícolas se tornavam crescentemente valorizadas.

O céu do Brasil, seção publicada entre janeiro e dezembro de 1933, trazia a reprodução dos mapas celestes, organizados pelo astrônomo Louis Cruls sobre o aspecto do firmamento na latitude do Rio de Janeiro, no dia 15 de cada mês, publicados em 1896 no Atlas celeste. Ao apresentar a seqüência de mapas a serem publicados, a RNE insistia na utilidade desse tipo de guia para os engenheiros, os geógrafos ou exploradores, facilitando o reconhecimento das estrelas indicativas de coordenadas geográficas. Apesar de referirem-se ao Rio de Janeiro, poderiam ser usados em todo o país, levando-se em conta pequenas 
alterações decorrentes de diferentes latitudes (RNE, jan. 1933, pp. 80-5). Cartilha de plantas, de animais, de técnicas agrícolas, do clima, a revista oferecia-se também como cartilha para que as pessoas de todo o país perscrutassem o céu e se localizassem no grande território que constituía o Brasil.

O conhecimento da matemática ligada à vida cotidiana, numa postura bastante afinada com os ideais escolanovistas, constituía a tônica da seção de Othelo Reis, em que explicava noções como proporção e infinito, além de expor regras para adições longas, tipos de medidas pouco usuais, instruindo sobre como somar rapidamente ou como calcular horas em diferentes latitudes, no caso de viagens. $\mathrm{O}$ professor Jonathas Serrano assinou algumas colunas nas quais ensinava a determinar o século de uma data, assim como entender os calendários e a noção de era, numa instrumentalização da matemática que apoiasse o conhecimento histórico.

O arqueólogo Alberto Childe, um dos colaboradores mais assíduos da revista, dedicou-se a escrever sobre culturas antigas, em especial gregas, romanas e egípcias. Seria uma contradição da proposta destinada ao conhecimento do Brasil? Certamente não, pois havia um objetivo maior nas longas explicações sobre o toucador na Antiguidade, os vasos gregos, os espelhos romanos ou mesmo a leitura dos hieróglifos, (tema esse que leva o autor a ensinar seus leitores a escreverem Museu Nacional e Quinta da Boa Vista em egípcio antigo). Afinal, como os visitantes do Museu poderiam entender os inúmeros objetos das salas sobre Grécia e Roma ou da majestosa sala sobre o Egito, com suas múmias e sarcófagos? Como criar um sentido para a sua visitação? Alberto Childe nada mais fazia do que ensinar os leitores a lerem o Museu, capacitá-los a percorrer suas salas, aumentado a eficácia pedagógica das exposições (Childe, nov. 1932, pp. 24-9).

Também as novas tendências da pesquisa antropológica do Museu eram divulgadas, com destaque para os artigos sobre antropogeografia de Raimundo Lopes. Para este estudioso, a jovem ciência da geografia humana apenas começava a ser debatida no Brasil, através das leituras de autores como Ritter, Reclus e, principalmente, Ratzel. Havia, entretanto, escritos como os de Euclides da Cunha, com sua visão geral da terra e da gente, ou de Alberto Torres, que lançara vistas profundas sobre as fontes naturais da vida social. Mais recentemente, enumerava os trabalhos de Roquette-Pinto, com sua etnografia sertaneja, os seus próprios estudos sobre os sambaquis e as estearias e os de Heloísa Alberto Torres sobre o espírito geográfico da cerâmica marajó (Lopes, ago.-set. 1933, pp. 17-23).

Uma série de outros artigos cumpria ainda a tarefa de instruir leituras do Brasil: Moisés Gikovate, também do Museu Nacional, foi certamente um autor que assumiu tal tarefa da forma mais eclética, abordando estudos sobre a geologia do território, sobre a origem das lendas, sobre a literatura brasileira, seus autores, seus estilos e 
sua periodização, além de explanações ilustradas de como os primitivos faziam fogo ou sobre a origem do calendário.

Acompanhando os ensinamentos para a 'leitura' da nação, algumas indicações para sua 'escrita' podem ser identificadas em seções como Lições de Desenho, assinadas por Seth, ou Palestras sobre Fotografias, de Guerra Duval. O desenho era visto como grande auxiliar da produção de conhecimento, acompanhando sua sistematização e divulgação, como pode ser muito bem exemplificado pelo seu generoso uso nas páginas da própria RNE. Os artigos ensinavam perspectiva, sombreamento e outras técnicas. A respeito da fotografia, eram apresentados os vários tipos de aparelhos, formas de revelação etc. Assim como o desenho, afirmava-se a fotografia como aliada da ciência, principalmente por permitir a visualização do movimento — através do cinema - e também possibilitar os registros do mundo microscópico. Em relação à arte, a reprodução de obras com fidelidade e rapidez antes impossíveis tornava-as acessíveis ao povo, como bem demonstravam as fotografias veiculadas pela RNE. Finalmente, a fotografia se esboçava como arte independente, já que o trabalho do fotógrafo trazia as marcas de sua interpretação pessoal (Guerra Duval, jan. 1933, pp. 64-9). Apresentando o desenho e a fotografia como estando ao alcance de todos, tais seções estimulavam seus leitores a produzirem desenhos e fotos de belas paisagens, de seus entes queridos, animais e plantas, num exercício de observação que ultrapassava a fronteira da criação artística.

Nesse plano, a RNE também se queria como um guia de formação do gosto estético, condição de um homem culturalmente superior, apto a desempenhar seu papel na constituição de uma grande nação. Além de artigos de divulgação científica, o leitor encontrava poemas e as já citadas reproduções de grandes pinturas, acompanhadas de biografias dos artistas. Reproduziam-se também algumas partituras, em um país onde o piano era um instrumento bastante difundido desde meados do XIX (Alencastro, 1997, p. 46; Mencarelli, 2003, pp. 201-13). As partituras publicadas eram versões facilitadas de hinos brasileiros, como o Hino da Independência, o Hino da Bandeira do Brasil e o Hino da Proclamação da República. Acompanhadas das letras, ensinavam a executar e a cantar as músicas principais da nação.

E no caso daqueles que não tinham nenhum conhecimento musical e para quem as partituras eram códigos insondáveis? Para estes a revista dedicou a seção Como Ouvir Música, escrita pelo frei Pedro Sinzig a convite especial de Roquette-Pinto. Com o objetivo de "fornecer uma chave" para que os leitores pudessem "entrar nesse imenso palácio da "Mil e uma noites"', ministrava orientações para a construção de uma familiaridade com o universo musical. Para gostar de música era necessário aprender sua linguagem, seus elementos, suas palavras e sua gramática. Assim, frei Pedro explicava o que eram os sons, o timbre dos diversos instrumentos, as formas de interpretação, o significado de 
termos como staccato, legato, pianíssimo, andante etc. (Sinzig, jan. 1933, pp. 11-4).

A RNE atuava, portanto, em várias áreas de divulgação do saber e da arte, capacitando seus leitores a conhecer o Brasil em sua flora, fauna, aspectos físicos, sociais e históricos, assim como torná-los aptos para a fruição de obras literárias, pictóricas e musicais. Mas também buscava transformar cada leitor em um colaborador na obra de educar o povo e formar a nação. Vários números contêm modelos de cartazes de alfabetização, a serem usados por quem se dispusesse a lutar contra o analfabetismo, talvez sensibilizado pelo desafio lançado na parte inferior do cartaz: "O sr. é brasileiro? É estrangeiro amigo do Brasil? - Não abandone a sua sorte os analfabetos - Trabalhe pelo Brasil!" (RNE, nov. 1932, p. 80).

A RNE procurava também divulgar métodos revolucionários de alfabetização, como o chamado 'Utilinda brincando', apresentado por uma professora ao Ministério da Educação. A partir de jogos e lotos educativos, baseados nos sons das palavras e letras e nas diferentes articulações da boca e dos lábios, uma criança maior, já alfabetizada, podia ensinar várias outras a ler. Isso poderia ser realizado em situações cotidianas, extraclasse e, principalmente, lúdicas. A revista publicou o artigo da educadora, com os detalhes do método e imagens ilustrativas, lançando um entusiástico apelo a todos. Através da personagem Utilinda, mostrava o principal atrativo do método, o de ser "útil, inda que brincando". Em uma estimativa mais que otimista, a revista projetava números: se sua tiragem alcançava 12.500 exemplares e cada um destes — uma vez distribuídos nas escolas e associações — encontrasse um leitor disposto a colaborar, capacitando uma criança a ser uma 'Utilinda' ("ou mesmo um galhardo Utilindo") que, por sua vez, alfabetizasse dez outros pequenos, seriam logo 125 mil jovens brasileiros beneficiados! (RNE, jul. 1933, p. 21; Almeida, jul. 1933, pp. 22-32).

A intenção de levar propostas educativas às pessoas nos mais variados e distantes locais delineava uma condição básica da produção da RNE que era a de ser criada na interseção de práticas ligadas à expansão do rádio e do cinema na sociedade brasileira, nas quais Roquette-Pinto, diretor do Museu Nacional e editor da revista, assumiu um papel decisivo e pioneiro. Para ele, "o cinema e o rádio no Brasil são a escola dos que não tiveram escola”. Impressa, a RNE trazia os ecos das transmissões radiofônicas e das pretensões contidas na defesa do cinema educativo.

\section{Entre impressos, projeções e ondas sonoras}

A RNE surgiu, como vimos, de um decreto de regulamentação das exibições cinematográficas no Brasil. O governo provisório da República considerava que o cinema - "meio de diversão de que o público já não prescinde" — oferecia largas possibilidades para a 
cultura popular, desde que "convenientemente regulamentado" (decreto 21.240). A taxa gerada financiou a revista, mas também contemplou a melhora do acervo de filmes educativos do Museu Nacional, assim como facilitava a entrada de filmes virgens, visando possibilitar a produção nacional de documentários educativos. Pelo que indicam alguns artigos já citados de Alberto Sampaio, havia iniciativas concretas de produção de filmes, certamente de pequena duração, para os quais ele realizou estudos referentes à carnaúba e ao babaçu.

O decreto criava ainda uma Comissão de Censura dos filmes a serem exibidos, formada por um representante do chefe de Polícia, outro do Juízo de Menores, pelo diretor do Museu Nacional, um professor e uma educadora. Desta forma, Roquette-Pinto tornou-se membro da Comissão. Mais do que isso, foi seu presidente. Os trabalhos eram intensos: somente no primeiro ano de existência, 1.200 filmes foram censurados. Dentre esses, alguns foram classificados como educativos, outros tiveram cenas cortadas ou foram proibidos, outros foram declarados impróprios para crianças ou menores de idade (Serrano, maio 1933, p. 2). Pouco depois o governo estabeleceu novas instruções, mais sistemáticas e detalhadas, estabelecendo a Comissão de Censura e Seleção de Filmes Educativos, em instrução assinada por Anísio Teixeira, então diretor do Instituto de Educação (Instruções, jun. 1933, pp. 19-29). É importante salientar que todas essas ações eram centralizadas pelo Ministério da Educação.

O único material publicitário veiculado pela RNE consistia nos anúncios dos filmes classificados como educativos, com a presença de grandes estúdios. Em Tapete mágico, da Fox-Films, o povo brasileiro teria o mundo aos seus olhos "em imagem e som". Igloo, da Universal Pictures, era uma verdadeira viagem à zona ártica, seus costumes e detalhes da "vida entre as neves eternas", num filme "auxiliar da educação nacional", assim como Eskimo, da Metro-Goldwyn-Mayer. Congorila, também da Fox, era o primeiro e único inteiramente filmado "no coração do deserto africano", mostrando gorilas em luta, uma mulher branca fugindo de um rinoceronte enraivecido, em edição especial para o Brasil, com explicações em português! Da mesma cepa, a produção nacional pelo Sono-Arte, África selvagem, mostrava a vida, os costumes, as mulheres, a ferocidade e o mistério dos ritos daquele continente. Além desses, a RNE anunciava o camundongo Mickey, em matinê no Cine Glória, Sinal da cruz de Cecil B. de Mille, com todo o esplendor de Roma em sua pompa, e muitos outros. Eram filmes recomendados pela revista, que neles apontava um conteúdo pedagógico.

Além de surgir ligada ao cinema, a RNE também se constituiu na interseção com o rádio. Roquette-Pinto possuía uma intensa atividade ligada à radiofonia, desde o início dos anos 1920. Encantara-se com as possibilidades desse meio de comunicação de massas em setembro de 
1922, quando o rádio foi apresentado no Brasil, na Exposição Comemorativa do Centenário da Independência, afirmando aos seus contemporâneos que assistir à aurora do rádio trazia a mesma emoção e esperança daqueles que tinham conseguido possuir e ler os primeiros livros. Passou a estudar radioeletricidade, obtendo em um laboratório uma pequena fonte de ondas contínuas. Criando um primeiro equipamento, fundou a Rádio Sociedade do Rio de Janeiro, em breve PRA-2, surpreendido e feliz por constatar que "aquela caranguejola, feita com bambu, alguns metros de fios de cobre, uma bobina de papelão e um fone de aparelho comum" funcionasse maravilhosamente. A primeira emissão ocorreu a 20 de abril de 1923. Lutou contra a legislação que proibia a propriedade particular de rádios receptores, obtendo sua extinção. Durante os anos 1920 era o speaker do Jornal da Manhã (Gouvêa Filho, op. cit., p. 50).

A PRA-2 possuía programas de divulgação científica e vários deles foram transcritos integralmente em artigos da RNE, como palestras de Affonso Taunay sobre bandeirantes, de Raimundo Lopes sobre antropogeografia, de Mello Leitão sobre biologia e muitas outras. Entusiasmado, conseguiu o apoio de outros intelectuais ligados à educação, como Teixeira de Freitas e Anísio Teixeira. Este último apoiou a fundação, no início dos anos 1930, da PRD-5, rádio-escola que contava com aparelhagem moderna e potente, montada no Instituto de Educação. No discurso de inauguração, Anísio Teixeira apontava o rádio como o meio que desencadeava a ruína das limitações do passado, suprindo a falta de escolas, a serviço da educação dirigida: o microfone era a "cátedra para espectadores em milhões”. Na mesma ocasião, Lourenço Filho apontava como o rádio e o cinema podiam ser fonte de corrupção, mas, como o fogo e a água, podiam fecundar a sociedade transpondo distâncias, devassando as paredes, insinuando-se por toda parte, levando "o esclarecimento e o conselho, a dúvida que estimula e a palavra de conforto". Provavelmente, o mesmo conforto moral da ciência e da arte que a RNE se propunha a levar aos seus leitores. Após os discursos, transmitiu-se 'A casinha pequenina', na voz de Bidu Sayão. Os ouvintes eram avisados sobre a possibilidade de receber gratuitamente, pelo correio, os esquemas, desenhos e mapas que os habilitariam a ter uma compreensão muito melhor dos cursos e das palestras ministrados pelo ar: bastava escrever para um endereço indicado, solicitando a remessa. Além da transmissão, tudo foi publicado no Jornal do Commercio e na RNE, que, por sua vez, passou a publicar muitas palestras seguidas de ilustrações, mapas etc. (RNE, jan. 1934, pp. 44-51)

Dos programas irradiados e transcritos na revista, havia um especial para crianças, chamado 'Tapete mágico', no qual tia Lúcia convidava os pequeninos a fazerem viagens por um tapete voador, que passava "por cima de todos os países, e por cima de todas as coisas, sem olhar 
distâncias", visitando locais como o Jardim Botânico e a Academia de Belas Artes, ou continentes distantes, como a África (Labarte, $\mathrm{jan} / \mathrm{fev} / 1934$, p. 55). As viagens podiam ser "encomendadas" pelo telefone da PRD-5 ou por carta, pelos ouvintes-mirins.

Impressos, ondas sonoras e imagens projetadas. No sonho daqueles homens, todos os meios de comunicação de massa seriam empregados na educação, transpondo distâncias, integrando o vasto território, retirando o povo da ignorância que lhe era atribuída, informando "cada vez mais o Brasil aos brasileiros", criando o futuro da nação (Roquette-Pinto, 1927).

\section{Do Brasil ao Museu, do Museu para o Brasil}

A edição da RNE foi realizada pelo Museu Nacional com a ativa colaboração dos seus membros na direção e na escrita de artigos, realização de desenhos e mapas, além da utilização das suas oficinas para a reprodução das fotos veiculadas em cada número. Tais práticas constituíram-se amalgamadas a uma transformação, naqueles anos, dos ideais do Museu, dos pressupostos que fundavam sua existência e da idéia de seu papel frente à sociedade. Dois fatores são especialmente relevantes. Um primeiro consiste na vocação educacional e popular da revista, cujo desejo era alcançar cada lar brasileiro, direta ou indiretamente. Ao lançarem uma revista visando mudar o Brasil, os intelectuais ligados ao Museu fizeram dela um elemento transformador da própria instituição à qual pertenciam Em segundo lugar, as coleções, seu incremento e manutenção ganhavam outro sentido.

O Museu foi criado em 1818, por decreto imperial de D. João VI, segundo o modelo dos museus metropolitanos, de caráter enciclopédico, expressão da tentativa de um "grande censo universal", reunindo tudo de forma a possibilitar ao seu visitante viajar por todos os continentes do globo apenas percorrendo alguns metros e abrindo algumas gavetas. Espécies distantes no tempo e no espaço poderiam "aparecer facilmente entre o conteúdo de uma vitrina e da próxima", em coleções cujo objetivo era representar todo o mundo (Lopes, op. cit., pp. 14, 53, 70). O empreendimento de um museu de história natural encontrava-se certamente ligado ao exercício do poder político do império português, que, em nítida consonância com outras nações européias, estreitava as relações entre o poder político e as ciências naturais. Museus e jardins apareciam como "agentes e produtos da história moderna, espaço no qual idéias sobre a natureza, economia e autoridade legítima interagiam com políticas concretas" do poder monárquico (Drayton, 2000, p. XV).

Algumas mudanças ocorreram por volta dos anos 1870, quando, sob diretoria de Ladislau Netto, o modelo de museu geral foi alterado. Novas áreas de conhecimento foram consolidadas, como a 


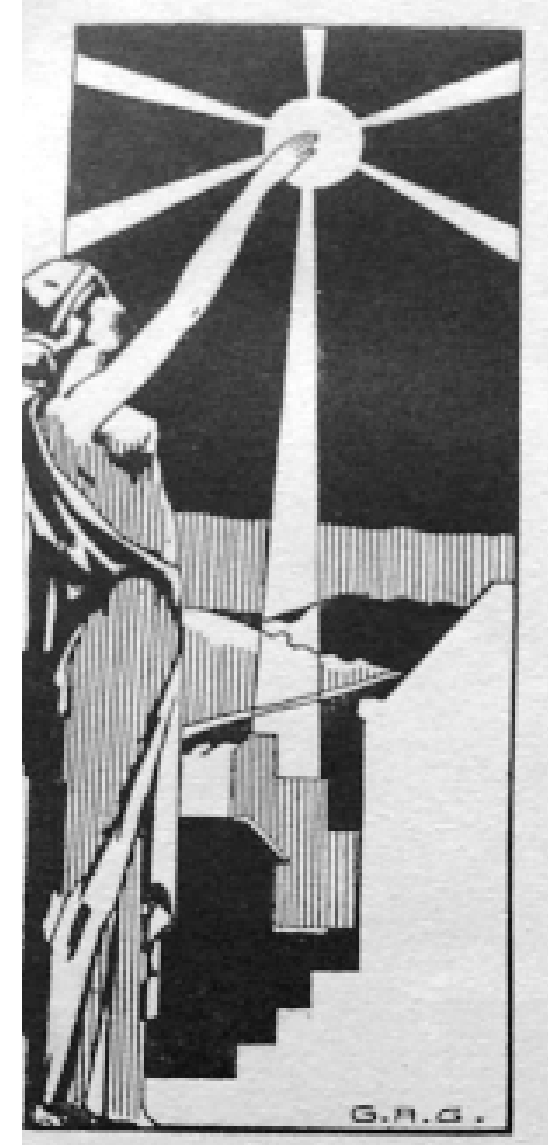

\section{REVISTA NACIONAL DE EDUCAÇÃo}

Miststzato DA rpuCaÇO I SATDE PUBLACA

em lodos as lanes do Brasil, o couforta mand da Cieneis o do Aate

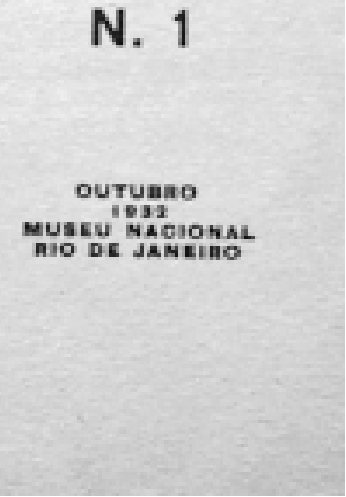

Figura 1 - Acima, a capa da primeira revista publicada. Ao lado, as capas em homenagem a Euclides da Cunha e Alberto Torres.
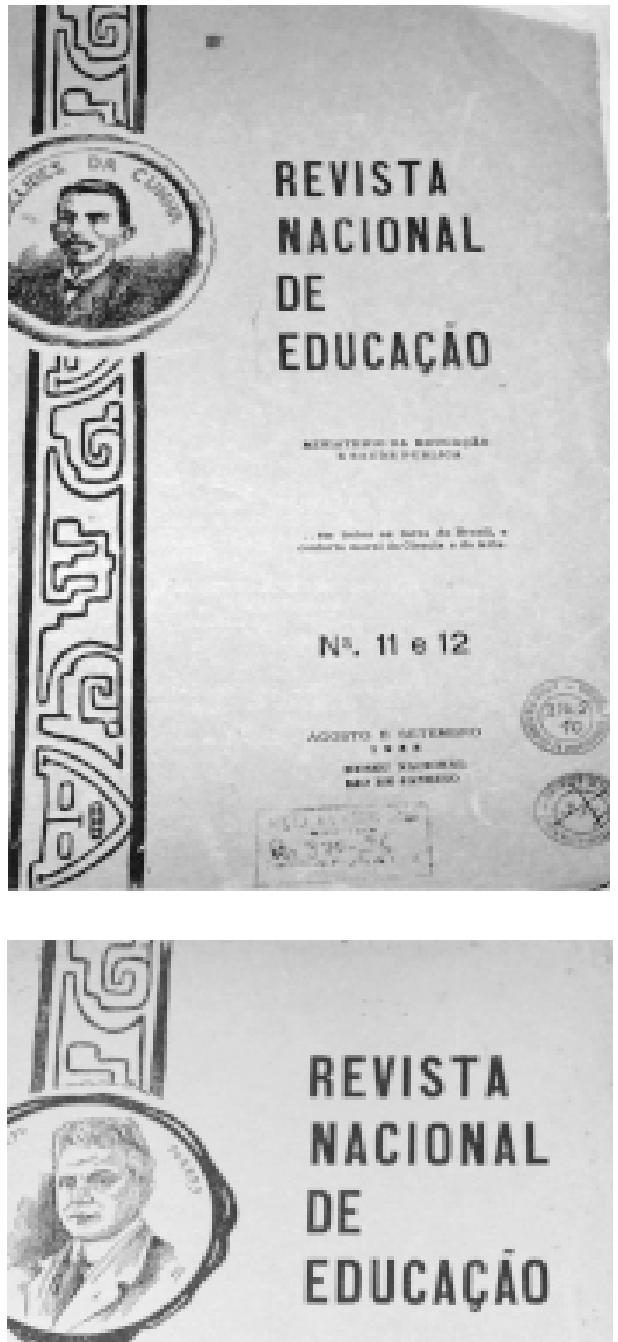

REVISTA NACIONAL

DE EDUCAÇÃO

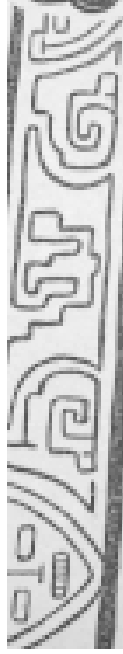

N. 6

Makgo

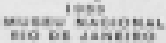



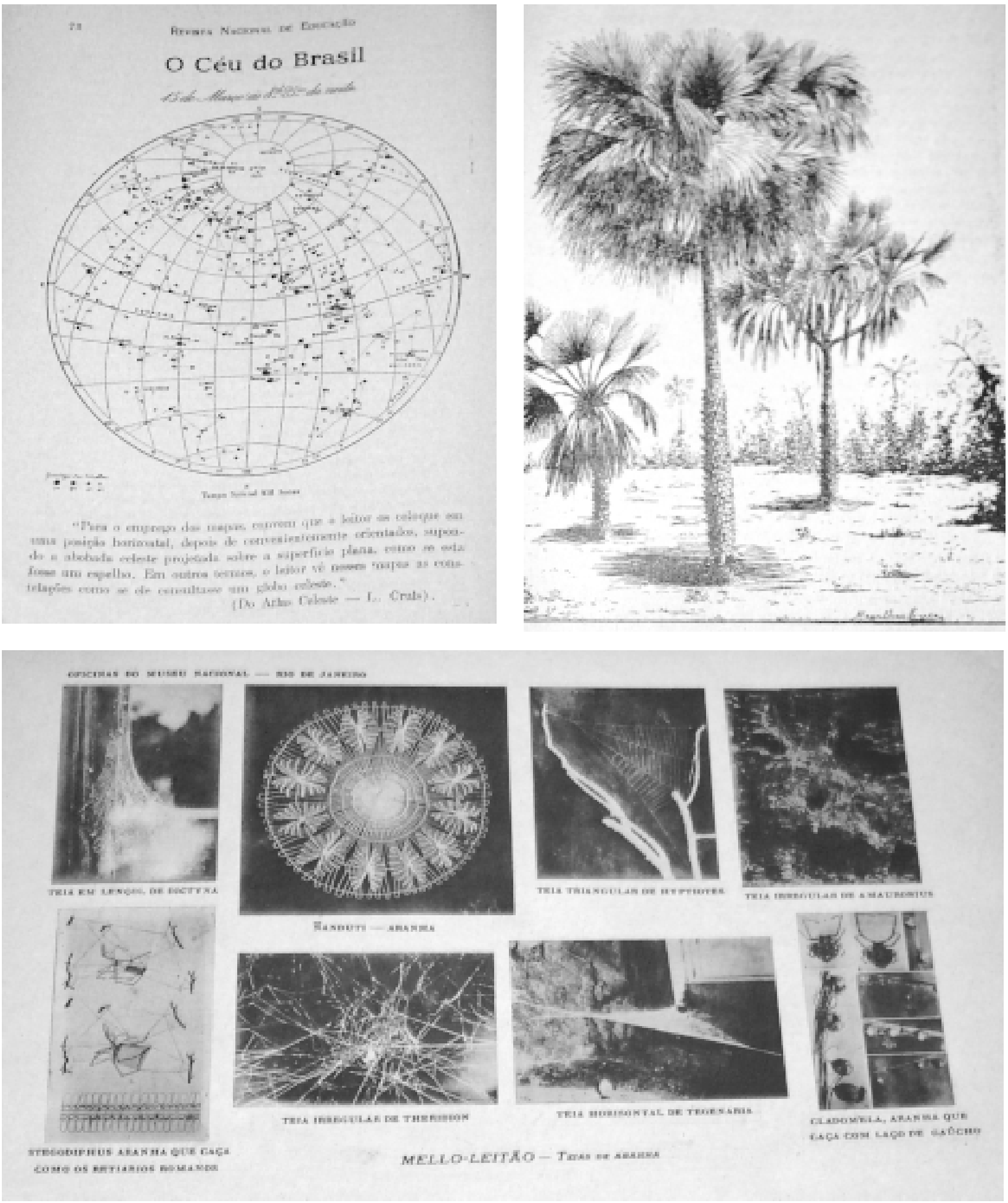

Figura 2 - Acima, à esquerda, o mapa do Céu do Brasil, de Louis Cruls. À direita, imagem que ilustra artigo de Alberto Sampaio sobre a carnaúba, ano 1(7), abril 1933, p. 57. Abaixo, imagens de teias de aranha, do artigo de mesmo nome de autoria de Mello-Leitão, ano 2 (9), junho 1933, página não numerada. Note-se que a rede indígena mostrada encontra-se até hoje na vitrine do Museu Nacional sobre aracnídeos. 

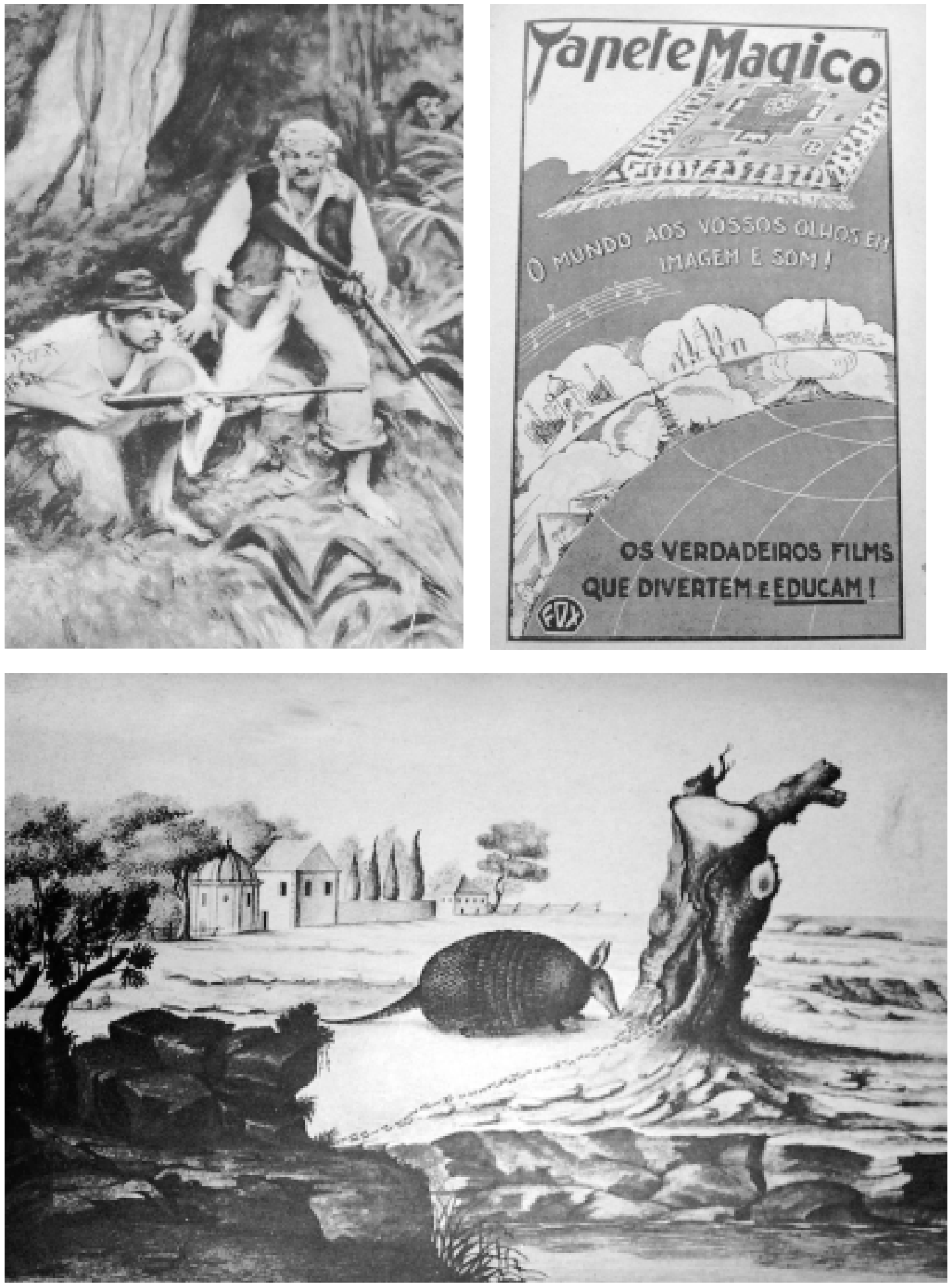

Figura 3 - Acima, à esquerda, 'Caipiras negaceando', de Almeida Júnior, ano , página não numerada. A esquerda, publicidade de filme educativo, ano 2 (20, 21), maio-junho 1934. Abaixo, estampa inédita de Alexandre Rodrigues Ferreira ano 1(1), outubro 1932. 
paleontologia, antropologia e etnologia. Iniciou-se a profissionalização das atividades dos que trabalhavam no museu, com a dedicação integral e a realização de concursos públicos para as vagas. Intensificaram-se os intercâmbios com museus europeus, norteamericanos e latino-americanos. Fundou-se uma publicação científica (os Arquivos do Museu Nacional) e deu-se início aos cursos de divulgação científica a partir de 1876 (Lopes, op. cit., p. 325). Tais cursos poderiam caracterizar um papel educativo do Museu Nacional. Entretanto, no âmbito da sociedade hierárquica e escravocrata imperial, o público ao qual se dirigiam marcava mesmo a concepção de "povo" então vigente: segundo o Jornal do Commercio, os assistentes dos cursos e palestras ministrados eram senhoras da mais distinta sociedade, homens de letras, empregados públicos e, não raras vezes, o próprio imperador (Domingues \& Sá, 1996, p. 82).

Como apontei, a disposição da nova publicação voltada para a divulgação científica do Museu Nacional, a Revista Nacional de Educação, era muito diversa daquela anteriormente firmada nos Arquivos, destinado a um público restrito e especializado. Por outro lado, essa era apenas uma "ponta de iceberg" na grande transformação pela qual passava aquela instituição. Envolvido em uma nova concepção de nação, palco de debates sobre a possibilidade da formação de um povo brasileiro através da educação, apostando em uma ação conjunta com o recém-criado Ministério da Educação, o Museu construía um novo papel para si através das práticas de seus membros, nas quais a RNE ocupou um papel primordial. Através de artigos publicados, os cientistas deram outro significado às coleções do Museu Nacional e às visitas de suas exposições.

As relações entre a RNE e o Instituto de Educação são parte do mesmo processo histórico de constituição de relações entre o Museu e as instituições de ensino do país. O Museu deveria ser um local de educação para todos os estudantes de todas as raças e condições sociais, futuros cidadãos brasileiros. Em texto destinado às professoras, Roquette-Pinto orientava como as visitas deviam ser precedidas de explicações sobre história natural, para que os estudantes não passassem pelas vitrines como "um fio d'água passa numa lâmina de vidro engordurado". Tornava-se necessário combater "a triste ignorância dos nomes das plantas e animais pelo povo do Brasil", onde todo animal era apenas "bicho". Para formar bons patriotas, futuros cientistas ou poetas, era necessário criar o amor à natureza, dando a ela um significado de beleza e glória (Roquette-Pinto, 1944, pp. 7-10). Anos depois, Heloísa Alberto Torres, diretora da instituição na década de 1940, manifestaria seu desejo de manter a orientação de Roquette-Pinto, segundo a qual a principal missão daquela casa era "difundir em nosso povo uma parte daquilo que ele precisa para vir a ser aquilo que merece". Para tanto, apontava escolas e professoras como público principal, franqueando-lhes as 
dependências do Museu, orientando a criação de museus escolares e enviando materiais diversos.

A orientação detalhada para a criação de museus naturais escolares foi objeto de inúmeros artigos publicados na RNE. O já citado curso de Carlos Vianna Freire, publicado em fascículos, foi introduzido por um artigo intitulado 'Toda escola deve possuir uma coleção de botânica', no qual o autor defendia a idéia como forma de garantir o contato direto dos alunos com a natureza. As professoras deviam montar o museu com flores, folhas e frutos trazidos pelos estudantes, construindo, portanto, um saber sobre a flora regional. O texto traz instruções de como colher, preparar, etiquetar e colar as plantas, raízes, caules, folhas, flores e sementes. Em seguida, Freire passou a escrever artigos sobre cada uma dessas partes das plantas (Freire, out. 1932, p. 23).

Alberto Sampaio, também botânico do Museu, assinou outro artigo sobre 'Como se classifica uma planta', em que ensinava com detalhes e muitas figuras a forma de exame de cada órgão do material, seu preparo e classificação (Sampaio, nov. 1932, pp. 3-15). A RNE publicou também vários artigos de membros da Sociedade dos Amigos de Alberto Torres, que, dentre várias ações, atuava em escolas do interior do Brasil. Seus membros participavam de cursos especiais no Museu Nacional, aprendendo técnicas práticas e econômicas de organizar coleções. Depois, ministravam palestras em locais diversos (Valente, ago.-set. 1933, pp. 65-84).

Ao orientar a criação de vários museus regionais, o Museu Nacional instituía também um novo papel para si. Mello Leitão, destacado zoólogo dessa instituição, criticava a noção de museu como um local de coisas raras, animais e plantas sensacionais, inéditas e bizarras. Para ele, o papel de um museu deveria ser o de ensinar, apresentar a natureza e sua verdade. A cada cem pessoas que percorriam suas galerias, 99 desconheciam a vida real dos seres, seu aspecto, seu habitat: era para essas 99 que o museu deveria existir! Distanciando-se do modelo de museu metropolitano, Mello Leitão assume uma defesa que acredito ter sido a postura predominante — ainda que certamente não a única — no Museu, naqueles anos: a instituição deveria ser "o repositório de tudo que há no país".

Conclamando seus leitores a serem também colaboradores, o autor solicitava que todos enviassem pequenos animais recolhidos em sua região, por mais comuns que lhes parecessem, como centopéias, lesmas, escorpiões, formigas. Seguem-se instruções detalhadas de como colocá-los em vidros cheios de álcool, embalados e protegidos, além da maneira de envio pelo correio. Com o auxílio de todos, as coleções do Museu Nacional teriam exemplares tipicamente brasileiros, tornando-se "sementeiras" de uma infinidade de pequenos museus espalhados pelos mais diversos estados, tornando nossas coisas "mais conhecidas e mais queridas". Tal 
material tornar-se-ia objeto de estudo, gerando artigos e estampas para a RNE, de modo que os leitores-colaboradores seriam brevemente recompensados ao verem os animais de suas regiões tornarem-se conhecidos de todas as outras, evidenciando o que era comum. Assim se constituiria uma zoologia brasileira, contemplando o particular e o geral, o uno e o múltiplo, numa concepção em que a diferença seria sempre remetida ao todo da nação. Em breve, os professores, ao abrirem os livros didáticos escritos no Brasil, depararia com espécies conhecidas pelos alunos, "em vez das figuras exóticas dos livros europeus" (Leitão, nov. 1933, pp. 96-8). É interessante observar que esse autor escreveu inúmeros livros didáticos de biologia, além de ter sido professor do Instituto de Educação do Rio de Janeiro.

Assim, do Brasil para o Museu, o envio de materiais possibilitaria ao Museu Nacional consolidar uma nova postura, assumida e defendida por vários de seus membros: ser um Museu do Brasil, para o Brasil. Diferenciando-se do museu metropolitano imperial de D. João VI, voltado para o mundo, o Museu Nacional dirigia-se à conquista do território nacional, ao inventário de sua natureza e de sua cultura, à instrução de seus habitantes e à formação de um povo.

\section{Conclusão}

A Revista Nacional de Educação teve curta duração: 21 números veiculados em 16 volumes, publicados entre outubro de 1932 e junho de 1934. Através de sua ampla tiragem, desejava alcançar cada escola, cada família. Aliada ao rádio e ao cinema, expressava bem a experiência de seu diretor, Roquette-Pinto, que percorrera imensidões ao lado de Cândido Rondon, valorizando a necessidade de transportes e comunicação através do território. Em seus exemplares, forma e conteúdo da edição estabeleceram um rico diálogo, dinamizando um ao outro. Seguindo a intenção de criar referências compartilhadas, propôs-se não apenas a uma leitura do Brasil, mas sobretudo a 'alfabetizar' seus leitores para uma leitura da nação. Ao longo dessa trajetória, seu diretor e muitos de seus autores construíram um novo papel para o Museu Nacional e, sobretudo, novas práticas de divulgação científica e de constituição de um saber especializado sobre o Brasil.

\section{REFERÊNCIAS BIBLIOGRÁFICAS}

Alencastro, Luis Felipe de 1997

De Luca, Tânia Regina 1999
'Vida privada e ordem privada no Império'. Em Fernando Novais (org), História da Vida Privada no Brasil, vol. 2, São Paulo, Companhia das Letras, pp. 11-94.

A revista do Brasil: um diagnóstico para a (N)ação. São Paulo, Ed. Unesp. 
Domingues, Helois \& Sá, Magali 1996

Drayton, Richard 2000

Gomes, Ângela

Maria de Castro 1999

Gouvêa Filho, Pedro. E. 1955

Grimal, Pierre 1984

Lima, Nísia Trindade 1999

Lobato, Monteiro 1984

Lopes, Maria Margaret 1997

Mencarelli, Fernando 2003

Veiga, Cynthia Greive 2000

Vidal, Diana Gonçalves 2001

\section{FONTES CITADAS:}

Almeida,

Maria da Glória jul. 1933

Brasil

Bouvier, E. jan. 1933

Childe, Alberto, ago/set. 1933

Childe, Alberto

Cunha, Euclides da mar. 1933

Cruls, Louis jan. 1993

Duval, Guerra jan. 1933

Fonseca, Álvaro Fróes jan. 1933
'O museu nacional e o ensino das ciências naturais no Brasil no século XIX'. Revista da Sociedade Brasileira para o Progresso da Ciência, 15, pp. 79-88.

Nature's government — science, Imperial Britain, and the 'improvement' of the world. Yale University Press.

História e bistoriadores, 2 a ed., Rio de Janeiro, Editora FGV.

'Roquette Pinto - antropólogo e educador'. Revista Brasileira de Estudos Pedagógicos. Rio de Janeiro, 24(59), jul./set., pp. 31-57.

Diccionario de mitologia griega y romana.

Barcelona, Editorial Paidós.

Um sertão chamado Brasil.

Rio de Janeiro, Revan.

'Velha praga'. Em Urupês, 30ª ed. São Paulo, Brasiliense, pp. 139-44.

O Brasil descobre a pesquisa científica —os museus e as ciências naturais no século XIX. São Paulo, Hucitec.

A voz e a partitura: teatro musical, indústria e diversidade cultural no Rio de Janeiro (1868-1908). Tese de doutoramento apresentada ao Departamento de História, Unicamp.

'Educação estética para o povo'. Em Lopes, Eliane Marta et al. 500 anos de educação no Brasil. Belo Horizonte, Autêntica, pp. 399-422.

O exercício disciplinado do olhar: livros, leituras e práticas de formação docente no Instituto de Educação do Distrito Federal (1932-1937).

Bragança Paulista, Editora da Universidade São Francisco.

Utilinda brincando.

Revista Nacional de Educação, 2(10), pp. 21-32.

Coleção das Leis da República dos Estados Unidos do Brasil de 1932.

Atos do Governo Provisório (abril a julho). Vol. II, Rio de Janeiro, Imprensa Nacional.

'Formigas agricultoras'.

Revista Nacional de Educação, 1(4), pp. 36-45.

'O toucador na Antiguidade'.

Revista Nacional de Educação 2(11/12), pp. 100-27).

'A leitura dos hieróglifos'.

nov. 1932 Revista Nacional de Educação, 1(2), pp. 24-8.

'xcerto'. Revista Nacional de Educação, 1(6), pp. 14-8.

'O céu do Brasil'.

Revista Nacional de Educação, 1(4), pp. 80-4.

'Palestras sobre fotografia'.

Revista Nacional de Educação, 1(4), 64-9.

'Discurso inaugural na Sociedade Carioca de Educação'.

Revista Nacional de Educação, 1(4), pp. 1-3. 


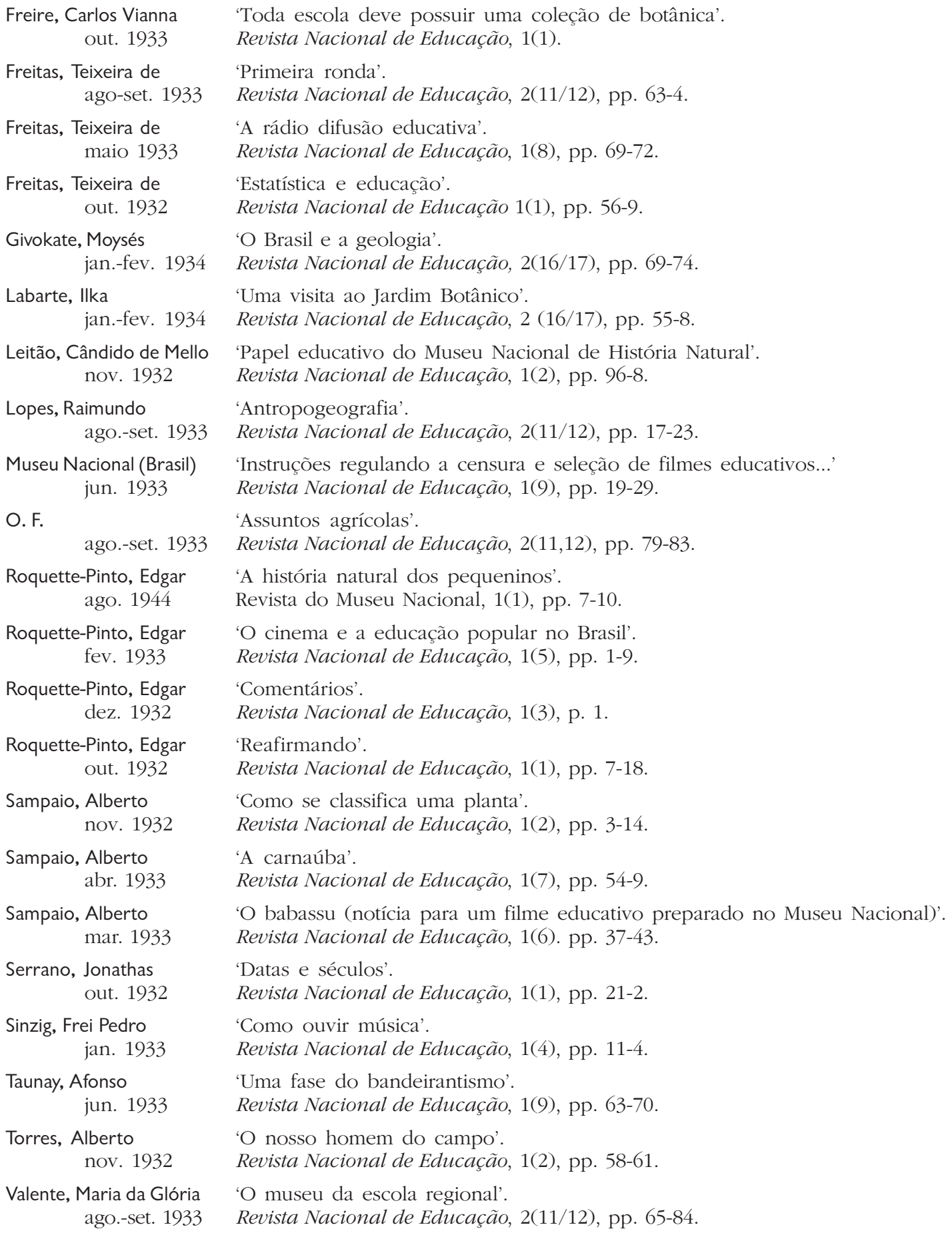

Valente, Maria da Glória ago.-set. 1933

'A história natural dos pequeninos'.

Revista do Museu Nacional, 1(1), pp. 7-10.

'O cinema e a educação popular no Brasil'.

Revista Nacional de Educação, 1(5), pp. 1-9.

'Comentários'.

Revista Nacional de Educação, 1(3), p. 1.

'Reafirmando'.

Revista Nacional de Educação, 1(1), pp. 7-18.

'Como se classifica uma planta'.

Revista Nacional de Educação, 1(2), pp. 3-14.

'A carnaúba'.

Revista Nacional de Educação, 1(7), pp. 54-9.

'O babassu (notícia para um filme educativo preparado no Museu Nacional)'. Revista Nacional de Educação, 1(6). pp. 37-43.

'Datas e séculos'.

Revista Nacional de Educação, 1(1), pp. 21-2.

'Como ouvir música'.

Revista Nacional de Educação, 1(4), pp. 11-4.

'Uma fase do bandeirantismo'.

Revista Nacional de Educação, 1(9), pp. 63-70.

'O nosso homem do campo'.

Revista Nacional de Educação, 1(2), pp. 58-61.

'O museu da escola regional'.

Revista Nacional de Educação, 2(11/12), pp. 65-84.

Recebido para publicação em abril de 2003.

Aprovado para publicação em julho de 2003. 